\title{
Pituitary Gland Metastasis of Breast Cancer: A Case Report
}

\author{
Cigdem OZKAN ${ }^{1}$, Cagatay ARSLAN², Mustafa K KILIC ${ }^{1}$, Mustafa ERMAN ${ }^{2}$, Kadri ALTUNDAG ${ }^{2}$ \\ ${ }^{1}$ Hacettepe University Faculty of Medicine, Department of Internal Medicine \\ ${ }^{2}$ Hacettepe University Institute of Oncology, Department of Medical Oncology, Ankara, TURKEY
}

\begin{abstract}
Pituitary gland is an uncommon site of metastasis for malignancies. However, breast cancer is the most common primary metastasizing to hypophysis in women. It may cause hormonal problems in different patterns due to mass affect and invasion to pituitary gland. We present a 53-year-old woman with HER-2 positive breast cancer presenting with intermittent symptoms of diabetes insipidus and rapidly developing pituitary mass treated with transsphenoidal surgery and thereafter the recurrent lesion with cyberknife stereotactic radiotherapy and systemic chemotherapy.
\end{abstract}

Keywords: Breast cancer, Pituitary gland, Metastasis

\section{ÖZET}

Hipofize Metastaz Yapan Meme Kanseri: Olgu Sunumu

Malign hastalıklarda nadiren hipofiz metastazı görülmektedir. Ancak, kadınlarda hipofize en sık metastaz yapan primer malignite meme kanseridir. Metastatik tümörün kitle etkisine veya hipofiz bezine invazyonuna bağlı olarak değişik kombinasyonlarda endokrin problemler görülebilir. Elliüç yaşında HER-2 pozitif meme kanseri olan bir kadın hastada intermitan diabetes insipitus semptomlarına neden olan ve hızlı gelişen metastatik hipofiz kitlesi ortaya çıkmıştır. Kitle transsfenoidal cerrahi ve arkasından rekürrens olduğunda cyber-knife stereotaktik cerrahi ve sistemik kemoterapi ile tedavi edilmiştir.

Anahtar Kelimeler: Meme kanseri, Hipofiz, Metastaz 


\section{INTRODUCTION}

The pituitary gland is an uncommon site for metastasis of malignant tumors. It is detected less than $1 \%$ of patients undergoing pituitary surgery and $5 \%$ in autopsy series of patients with known malignancy. ${ }^{1}$ Breast and lung cancer are the most common primary neoplasms metastasizing to the hypophysis in women and men respectively. ${ }^{2-4}$ Although breast cancer is the most common primary tumor, diagnosis of pituitary insufficiency and metastasis can be difficult in the follow up. Cancer patients may have signs and symptoms similar with pan-hypopituitarism and it can easily be attributed to the chemotherapy recieved or the primary disease especially in metastatic stage. Clinicians must bear pituitary insufficiency in mind due to metastasis to hypophysis in breast cancer patients.

\section{CASE REPORT}

A 53-year-old female admitted with a 3 month history of polyuria, polydipsia and fatique. She had a diagnosis of breast cancer in 2003. She had modified radical mastectomy with lobular carcinoma and infiltrative ductal carcinoma (mixed type) histopathology (T2N2M0). Immunohistochemical staining for estrogen and progesterone receptors were both negative. However, overexpression of HER2 was detected by immunohistochemistry. Adjuvant chemotherapy with 6 cycles of epirubicin and cyclophosphamide and locoregional radiotherapy were both administered. Three years later, patient developed liver and bone metastasis. Because of metastatic disease she received 9 cycles of combination regimen of weekly paclitaxel, trastuzumab and carboplatin followed by eight weeks of paclitaxel and trastuzumab combination after stopping carboplatin because of the allergic reaction. During the follow up NCI grade 3-4 neuropathy occurred with paclitaxel, and she was switched to receive a combination regimen of capecitabine with trastuzumab. While she was on this chemotherapy she complained newly occurring polyuria, polydipsia and fatique approximately four years after the diagnosis of breast cancer. She had a mild, intermittent headache but did not have any other cranial symptoms. Later on she developed constipation, cold intolerence, somnolence, confusion and bradycardia. Her laboratory results were consistent with central diabetes insipidus, hypocortisolism and secondary hypothyroidism. Her follicle stimulating and luteinising hormone and estrogen levels were decreased. However patient was post-menopousal after adjuvant chemotherapy she received. Routine laboratory tests showed mild elevation of liver function tests, anemia and mild thrombocytopenia. The patient was diagnosed as pan-hypopituitarism. The patient's cranial and hypophyseal MRI revealed sellar mass consistent with hypophyseal macroadenoma with a diameter of $2.5 \mathrm{~cm}$ (Figure $1 \mathrm{~A}$ and $1 \mathrm{~B}$ ). She was put on desmopressin acetate, prednisolone followed by levothyroxine sodium replacement therapy. Her symptoms resolved. In the fourth year of diagnosis trastuzumab and capecitabine was discontinued because of the decreased ejection fraction of left ventricle on echocardiography and since she couldn't tolerate capecitabine because of NCI grade 3-4 hand-foot syndrome. The patient was switched to a metronomic treatment of oral cyclophospamide and methotrexate regimen.

The patient underwent trans-sphenoidal surgery. Breast cancer metastasis to the pituitary gland was established histologically. Immunohistochemical staining was strongly positive for pan-cytokeratin and GCDFP-15, positive for cerbB-2 and negative for estrogen and progesteron receptors as the primary pathology. Two months later following surgery, postoperative MRI revealed recurrent lesion compressing optic chiasm and extending towards bilateral cavernous sinuses. A cyberknife stereotactic radiotherapy was performed. During ten months of follow up no recurrent sellar mass was observed. In this period the patient received capecitabine and lapatinib combination treatment. Then progression in bone and liver metastasis was noted and while we were planning to switch her chemotherapy to gemcitabine she was again admitted to our hospital because of nausea, fatique and jaundice. Replacement therapy for pan-hypopituitarism was re-started immediately. Laboratory tests showed elevation in liver function tests and hyperbilirubinemia. An abdominal ultrasonography revealed diffuse metastatic lesions in the liver. Approximately in one week liver failure developed and the patient died. 




Figure 1A. Sagittal MRI showing pituitary mass

\section{DISCUSSION}

Hypophyseal metastasis of cancers is an uncommon occasion. Also less than $1 \%$ of hypohyseal masses surgically resected are diagnosed as metastatic tumours. ${ }^{1}$ The metastasis to the pituitary more commonly involves posterior lobe alone or in combination with anterior pituitary in $85 \%$ of cases, while anterior pituitary alone is involved only in $15 \% .{ }^{4}$ Breast and lung cancer are the most common primary neoplasm metastasizing to the pituitary in women and men respectively. ${ }^{2-4}$ Breast cancer being the most common cancer metastasizing to the pituitary can be explained with the prolactin rich environment of the pituitary enhancing the proliferation of tumor cells of breast.-5

The most common symptom of pituitary metastasis seems to be diabetes insipidus. ${ }^{1,6-10}$ Visual impairment resulting from optic chiasm compression seems to be second most common presentation..$^{1,12-15}$ Complete or partial pituitary insufficiency is the third most common presentation of pituitary metastases. ${ }^{1,5-18}$ It is usually associated with a mass effect of a large tumour.

Diagnosis of pituitary metastasis might be missed in absence of overt clinical symptoms of hormonal insufficiency and vision problems caused by a large metastatic hypophyseal mass compressing chi-

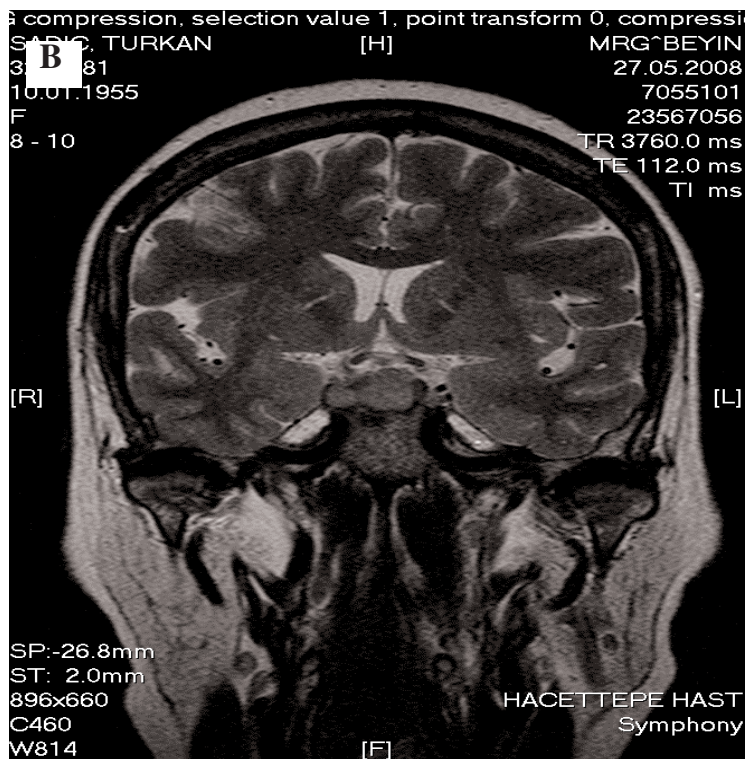

Figure 1B. Coronal section of MRI showing pituitary mass

asma opticum. Patients may have signs and symptoms of nausea, vomitting, fatique, weight loss could be seen in pan-hypopituitarism and also be easily attributed to the side effects of chemotherapy received or the primary malignancy. ${ }^{1}$ Thus panhypopituitarism and pituitary metastasis can be underdiagnosed. However when diabetes insipidus developed polyuria and polydipsia becomes generally a frank symptom makes patient admitting to doctor. Diagnosis of pituitary metastasis is also difficult. Because up to $16 \%$ of patients with overt malignancy may also have pituitary adenoma. ${ }^{5,19}$ However, diabetes insipidus is reported less than $1 \%$ of pituitary adenomas. ${ }^{5.8}$ Sudden onset of diabetes insipidus, the rapidity of symptom development and a rapidly growing sellar tumor suggest pituitary metastasis. ${ }^{5,8,11}$ Diabetes insipidus is the most important criterion for differentiation of pituitary metastasis from adenomas. ${ }^{1,10}$ Thus the clinician must be suspicious of pituitary metastasis in a patient with known cancer and clinical presentation listed above. However, metastasis is usually suspected during surgery and diagnosed histologically after surgery. ${ }^{1,19}$ A residual or recurrent sellar mass might be treated with modern radiotherapy techniques as cyberknife stereotactic radiosurgery as in our case regarding the difficulty of a second surgery. 
Prognosis of pituitary metastasis is poor..$^{1,49}$ Median survival in clinical series is 6 to 7 months..$^{5-7}$ But the prognosis and survival primarily depend on characteristics of the tumor. ${ }^{1,5,19,20}$ However there is no survival data specific to the pituitary metastasis of breast cancer.

In conclusion; pituitary metastasis of breast cancer is an uncommon problem. MRI of hypophysis must be performed whether symptoms related to suppression of chiasma opticum present or not. However pituitary adenomas might also co-exist in metastatic breast cancer patients. Clinical presentation might occur mostly with diabetes insipidus but also insufficiency of other hormones of pituitary gland. An uninterrupted replacement treatment of pituitary hormones is crucial.

\section{REFERENCES}

1. Komninos J , Vlassopoulou V , Protopapa D, et al. Tumours metastatic to the pituitary gland: Case report and Literature Review. J Clin Endocrinol Metab 89: 574-580, 2004.

2. Chiang MF, Brock M, Palt S. Pituitary metastases. Neurochirurgia 33: 127-131, 1990.

3. Houck WA, Olson KB, Horton J. Clinical features of tumor metastasis to the pituitary. Cancer 26: 656-659, 1970.

4. Rajput R, Bhansali A, Dutta P, et al. Pituitary metastasis masquerading as non-functioning pituitary adenoma in a woman with adenocarcinoma lung. Pituitary 9: 155-157, 2006.

5. Morita A, Meyer FB, Laws Jr ER. Symptomatic pituitary metastases. J Neurosurg 89: 69-73, 1998.

6. Sioutos $P$, Yen $\vee$, Arbit E. Pituitary gland metastases. Ann Surg Oncol 3: 94-99, 1996.

7. Houck WA, Olson KB, Horton J. Clinical features of tumor metastasis to the pituitary. Cancer 26: 656-659, 1970.

8. Branch Jr CL, Laws Jr ER. Metastatic tumors of the sella turcica masquerading as primary pituitary tumors. J Clin Endocrinol Metab 65: 469-474, 1987.

9. Delattre JY, Castelain C, Davila L, et al. Metastasis to the pituitary stalk in a case of breast cancer. Rev Neurol 146: 455-456, 1990.

10. Schubiger $\mathrm{O}$, HallerD Metastases to the pituitaryhypothalamic axis. An MR study of 7 symptomatic patients. Neuroradiology 34: 131-134, 1992.

11. Freda PU, Post KD. Differential diagnosis of sellar masses. Endocrinol Metab Clin North Am 28: 81-117, 1999.
12. Megan Ogilvie C, Payne S, Evanson J, et al. Lymphoma metastasizing to the pituitary: an unusual presentation of a treatable disease. Pituitary 8: 139146, 2005.

13. Kato $T$, Leki R, Hashimoto E, et al. Pituitary stalk metastasis from lung cancer, preceding diabetes insipidus-case report and clinical review of the literature. Nihon Kokyuki Gakkai Zasshi 41: 48-53, 2003.

14. Murata $Y$, Ogawa $Y$, Yokoe I, et al. Pituitary stalk metastasis from breast cancer treated with systemic chemotherapy. Oncol Rep 10: 1973-1975, 2003.

15. McCormick PC, Post KD, Kandji AD, Hays AP. Metastatic carcinoma to the pituitary gland. $\mathrm{Br} \mathrm{J}$ Neurosurg 35: 51-54, 1989.

16. Sturm I, Kirschke S, Krahl D, Dorken B. Panhypopituitarism in a patient with breast cancer. Onkologie 27: 480-482.

17. Pinet C, Raholimina V, Ferri RM, Kleisbauer JP. Panhypopituitarism secondary to pituitary metastases. Presse Med 29: 17-18, 2000.

18. Leramo OB, Booth JD, Zinman B, et al. Hyperprolactinaemia, hypopituitarism and chiasmal compression due to carcinoma metastatic to the pituitary. Neurosurgery 8: 477-480, 1981.

19. Gokowski F, Trofimiuk M, Czepko R, et al. Two rare cases of pituitary metastases from breast and kidney cancers. Exp Clin Endocrinol Diabetes 115: 537-540, 2007.

20. Ntyonga-Pono MP, Thomopoulos P, Luton JP. Pituitary metastases. Three cases. Presse Med 28:15671571, 1999.

\section{Correspondence}

Dr. Çağatay ARSLAN

Hacettepe Üniversitesi Onkoloji Enstitüsü

Tıbbi Onkoloji Bilim Dalı

06100 Sihhiye, Ankara / TURKEY

Tel: (+90.312) 3052941

Fax: (+90.312) 3066226

Email: arslancagatay@yahoo.com 